\title{
DO TRANSISTOR AO CELULAR: anotações históricas sobre transformações da reportagem radiofônica a partir de tecnologias
}

\author{
FROM TRANSISTOR TO CELL PHONE: historical notes on \\ transformations of radio reportage using Technologies
}

\author{
Valci Regina Mousquer ZUCULOTO ${ }^{1}$ \\ Arnaldo ZIMMERMANN²
}

Universidade Federal de Santa Catarina| Brasil

\begin{abstract}
Resumo
O artigo (re)visita a trajetória do rádio no Brasil com foco em tecnologias que oportunizaram ao meio explorar suas características de mobilidade, imediatismo, instantaneidade e ubiquidade na produção de reportagens. Reflete-se, em perspectiva de (re)construção histórica, o percurso desde a chegada do transistor na década de 1950 até a consolidação do celular no país, inovações que permitiram ao rádio protagonizar a cobertura jornalística através da reportagem. Na trajetória da reportagem radiofônica e sua relação com as inovações técnicas e tecnológicas buscase bases para entender a presente reconfiguração do radiojornalismo. É pesquisa exploratória, recorrendo-se à análise documental e revisão bibliográfica, com subsídios da história.

Palavras-chave

Radiojornalismo; Reportagem Radiofônica; História do Rádio; Tecnologias.

\section{Abstract}

The article (re) visits the trajectory of radio in Brazil with a focus on technologies that have made it possible for the medium to explore its characteristics of mobility, immediacy, instantaneity and ubiquity in the production of reportages. It is reflected, in the perspective of historical (re) construction, the path from the arrival of the transistor in the 1950s to the consolidation of the cell phone in the country, innovations that allowed the radio to lead the news coverage through reportage. In the trajectory of radio reportage and its relationship with technical and technological innovations, we seek bases to understand the present reconfiguration of radio journalism. It is exploratory research, using documentary analysis and bibliographic review, with subsidies from history.

Keywords

Radio journalism; Radio Reportage; Radio History; Technologies.
\end{abstract}

\section{RECEBIDO EM 07 DE ABRIL DE 2020}

ACEITO EM 11 DE MAIO DE 2020

1 Professora de graduação e pós-graduação em Jornalismo na UFSC. Doutora em Comunicação (PUCRS).
Pós-Doutora (ECO-UFRJ), Coordenadora da Rede de Pesquisa em Radiojornalismo (RadioJor/SBPJor) e
da Rádio Ponto UFSC. Diretora Científica da Associação Brasileira de Pesquisadores de História da Mídia
(ALCAR). Líder do Grupo de Investigação em Rádio, Fonografia e Áudio (Girafa), certificado no CNPq.
Contato: valzuculoto@hotmail.com
${ }^{2}$ Doutorando em Jornalismo na UFSC. Mestre em Jornalismo (UFSC). Especialista em Publicidade (FURB).
Graduado em Jornalismo (UNISOCIESC) e Letras (FURB). Integrante do Grupo de Investigação em Rádio,
Fonografia e Áudio (Girafa) do PPGJOR/UFSC. Bolsista Capes. Contato: arnaldozimmermann@gmail.com.

João Pessoa-Brasil | ANO 7 VOL.7 N.1 | JAN./JUN. 2020 | p. 220-238 


\section{AिएटORA}

Valci Regina Mousquer ZUCULOTO . Arnaldo ZIMMERMANN

\section{Introdução}

mobilidade está presente com maior ênfase no rádio desde a
segunda metade do século 20, tanto nos equipamentos de
recepção e nos hábitos de escuta do ouvinte como na emissão das mensagens, especialmente nas transmissões ao vivo e simultâneas direto do palco dos acontecimentos. Este artigo busca (re)construir a trajetória da reportagem radiofônica pela ótica dos recursos tecnológicos que permitiram seu impulsionamento, transformando o meio rádio em protagonista dos acontecimentos, especialmente quando a demanda do tripé apuraçãoprodução-circulação passa a exigir velocidade e encurtamento do lapso temporal entre o fato gerador da notícia e a transmissão do conteúdo ao público.

A facilidade histórica de transmissão em tempo real garantiu ao meio as características de imediatismo e instantaneidade. A ubiquidade possível pelo uso de equipamentos móveis faz o rádio gerar diferentes graus do vivo, retratados, sobretudo, na realização de reportagens. Apesar de tais características estarem presentes no meio desde os seus tempos pioneiros, condições técnicas e tecnológicas, ao longo de sua história, demonstraram-se primordiais para a sua efetivação, consolidação e engajamento em um processo de evolução. E assim, o processo vem conjugando, concomitantemente, transformações nos modos de fazer e uso da linguagem, com utilização de novos aparatos técnicos e tecnológicos.

O objetivo geral deste artigo ${ }^{3}$, portanto, é evidenciar as principais e mais determinantes inovações tecnológicas que potencializaram e constituíram a reportagem radiofônica externa, facilitando a intervenção ao vivo das emissoras, diretamente do local e no exato momento dos acontecimentos. 0 próprio advento do rádio é por nós compreendido como resultado de inovação

3 Originalmente apresentado no GP Rádio e Mídia Sonora, XIX Encontro dos Grupos/Núcleos de Pesquisa em Comunicação, evento do XШI Congresso Brasileiro de Ciências da Comunicação, em 2019, constando de seus anais. Revisado e ampliado. 
tecnológica em comparação com outros meios de comunicação. E já na sua criação, expressou potencial de explorar características de mobilidade, imediatismo, instantaneidade e ubiquidade. Assim, desenvolve-se aqui discussão, sobretudo, de como os recursos radiofônicos técnicos e tecnológicos, desde a invenção do transistor até a chegada e a consolidação do uso dos celulares nas reportagens, possibilitaram ao rádio brasileiro protagonizar a cobertura dos acontecimentos através da reportagem externa.

Nosso recorte temporal, deste modo, concentra-se entre a década de 1950 e os dias atuais. O foco central da análise é na utilização de tecnologias para a realização de reportagens radiofônicas externas, traçando demais avanços obtidos pelo rádio e sua reportagem como elementos paralelos e complementares.

As principais opções metodológicas são a análise documental e a revisão bibliográfica, recorrendo-se, para a sistematização de dados (re)coletados e reflexões acerca destes, também a aportes da história, em especial da história pública e da história da comunicação e do jornalismo. 0 apoio em subsídios de pesquisa da história pública vem permitindo que nossos estudos com orientações históricas evidenciem e observem por meio de fontes, dados, vestígios até incomuns ou pouco utilizados neste tipo de investigação (MAUAD, ALMEIDA, SANTHIAGO, 2016; MAUAD, SANTHIAGO, BORGES, 2018). No presente artigo, recorremos em especial à revisão de estudos anteriores sobre o rádio, o radiojornalismo e a reportagem radiofônica.

Assim, trata-se de uma pesquisa histórica, exploratória, com entendimento de que ao se debruçar sobre a trajetória de constituição da reportagem radiofônica imbricada com principais e mais determinantes inovações técnicas e tecnológicas que a impactaram, pode-se compreender melhor o presente e futuro do radiojornalismo. Nossa perspectiva compartilha com compreensões de estudiosos da história da comunicação como Marialva Barbosa, para quem a história pode e deve ser submetida a revisões. 


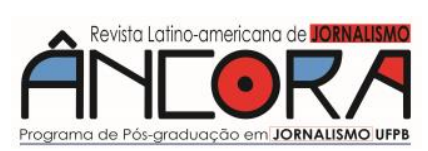

Valci Regina Mousquer ZUCULOTO . Arnaldo ZIMMERMANN

A história da comunicação, como qualquer história, passa periodicamente por revisões, seja porque foi descoberto ao acaso um arquivo precioso e que deixa ver sistemas de comunicação em toda sua complexidade, seja porque as inquietações do tempo obrigam a direcionar o olhar para o passado, tentando compreender turbilhões e redemoinhos de mudanças que avançam sobre cada um de nós no mundo que denominamos contemporâneo. (BARBOSA, 2017, p. 7)

Já o percurso teórico para a análise parte da localização histórica do rádio com o advento das primeiras reportagens externas, baseada em autores como Ortriwano (1990, 2002-2003), Bespalhok (2005, 2006), Zuculoto (2012), até mais recentes equipamentos que garantiram o caráter móvel deste meio de comunicação, sustentado em trabalhos de pesquisadores como Lopez (2009), Gomes (2014), Ferraz (2016) e Gambaro (2019).

\section{Jornalismo escasso e sem reportagens no "Rádio Pioneiro}

Apesar da rápida evolução na programação radiofônica brasileira no período denominado de "Rádio Pioneiro", entre os finais dos anos $1910^{4}$ e da década de 1930, o jornalismo profissional ainda não fazia parte do conteúdo diário nem das tarefas cotidianas dos novos redatores e equipes de produção.

Neste período, a notícia "é ainda incipiente e produzida a partir de simples transposições dos jornais impressos ou em forma de comentários das suas informações" (ZUCULOTO, 2012, p.45). A ausência de técnicas de produção que melhor aproveitassem as inovadoras especificidades do meio, como a mobilidade e o imediatismo, persistiu ainda por algumas décadas desde as pioneiras transmissões. Já ao pesquisar a constituição histórica da notícia de rádio no Brasil, foi possível observar que nem mesmo os textos das primeiras emissões eram totalmente adequados às características e linguagem

\footnotetext{
${ }^{4}$ Ressalta-se que na concepção dos autores deste artigo, o advento do meio no Brasil é localizado em 1919, com o início das transmissões da Rádio Clube de Pernambuco. Mas também não deixamos, na (re)visita à história do rádio que aqui procedemos, de citar os testes de 1922, com as irradiações das comemorações do centenário da independência do país, no Rio de Janeiro. Embora considerada a data "oficial" do início do rádio no Brasil, acolhemos e defendemos o pioneirismo da Rádio Clube de Pernambuco, em consonância com nossos referenciais baseados em aportes da nova história, sobretudo da história pública, e do entendimento que é preciso, especialmente quando avançam ou se modificam nossos conceitos, revisar a história, até mesmo aquela já pesquisada por nós.
} 
DO TRANSISTOR AO CELULAR: anotações históricas sobre transformações da reportagem radiofônica a partir de tecnologias

específicas do meio. Ainda não se utilizava a maior parte do seu potencial para veiculação informativa.

A simples leitura de jornais ao microfone, na primeira fase do rádio, demonstra que o radiojornalismo no Brasil começou sem reportagem. Conforme Bespalhok (2005, p. 2-3): "tinha-se, desde o início, a figura do apresentador que narrava as notícias ou fazia comentários". Não existia, assim, a voz do repórter ou das fontes. A autora compara o nascimento do radiojornalismo sem a reportagem como, semelhantemente, ocorreu nos meios impressos.

Antes mesmo do surgimento da reportagem como conhecemos hoje no rádio brasileiro, um importante marco divisor no jornalismo radiofônico se evidencia como consequência da Segunda Guerra Mundial: o "Repórter Esso", que no Brasil fundou o radiojornalismo nacional e padronizou o segmento comercial do nosso rádio:

O aperfeiçoamento dos equipamentos e o desenvolvimento de sistemas de transmissão de maior alcance são consequências que ressaltam o aspecto jornalístico do rádio. Nesse contexto surgem no Brasil os primeiros programas que, em sua evolução, serão os pilares de sustentação que darão origem ao radiojornalismo praticado até nossos dias: o Repórter Esso e o Grande Jornal Falado Tupi. (ORTRIWANO, 2002-2003, p. 72).

Devido à Guerra, o rádio se tornou o que Beltrão $(1976$, p.26) classifica de "informação de superfície", uma especificidade do radiojornalismo que, mesmo passado o conflito, identificamos que vai permanecer como a base dos noticiosos radiofônicos.

No período inicial da chamada "Era de Ouro" do rádio, na década de 1940, o radiojornalismo tem como principal fonte de informações as agências de notícias, que influenciam e ditam rumos ao jornalismo praticado no Brasil. Em contraste aos grandes investimentos na produção dos programas de espetáculo, como radionovelas e shows de auditório, o jornalismo funcionava ainda sem a apuração por repórteres e outros profissionais em contato direto 


\section{ANEORA}

Valci Regina Mousquer ZUCULOTO . Arnaldo ZIMMERMANN

com as fontes ou nos locais dos acontecimentos. Neste período, apesar de o rádio brasileiro já ter superado em parte a precariedade técnica que marcou seus tempos pioneiros, ainda não é comum a prática da reportagem externa com maior utilização das características do imediatismo e instantaneidade.

\section{O transistor como principal tecnologia de impulso à reportagem de rádio}

Com o fim da "Era de Ouro" no rádio brasileiro em meados da década de 1950, é dada a primeira e grande sentença de morte para este meio que figurou como o mais popular até então. A chegada da televisão não representou apenas uma concorrência, mas um forte golpe com o deslocamento dos maiores atrativos de um meio exclusivamente sonoro para um meio audiovisual. Para Ortriwano, a TV "ocupou o primeiro plano entre os meios de comunicação, levando consigo as verbas publicitárias, os profissionais e a audiência" (ORTRIWANO, 1990, p.82).

Neste período, denominado de "Pós-televisão", entre a década de 1950 e 1970, o rádio conseguiu driblar sua decretada morte com uma série de novos instrumentos tecnológicos.

Terminada a fase de ouro, o rádio encontra na eletrônica seu maior aliado. Uma série de inovações tecnológicas são especialmente favoráveis ao renascimento do rádio e à transmissão jornalística. Entre elas, o gravador magnético, o transistor, a frequência modulada e as unidades móveis de transmissão (ORTRIWANO, 2002-2003, p. 76).

Estas inovações a que se refere Ortriwano representam marcos que modificaram a qualidade de transmissão e recepção radiofônica, além de agilizar e tornar ainda mais imediata a emissão da reportagem externa. Possibilitaram, por exemplo, transmitir além de notícias sintéticas que caracterizavam sobremaneira o jornalismo radiofônico à época, veiculando mais informações em formato exato de reportagem, incluindo mais dados e fontes. Entretanto, no caso do gravador magnético, a inovação também trouxe maior controle sobre a informação veiculada.

João Pessoa - Brasil | ANO 7 VOL.7 N.1 | JAN./JUN. 2020 | p. 220-238 225 
DO TRANSISTOR AO CELULAR: anotações históricas sobre transformações da reportagem radiofônica a partir de tecnologias

[...] se, por um lado, o gravador magnético deu ao rádio maior agilidade, mais versatilidade, barateou custos, pois programas - ou trechos - poderiam ser repetidos e melhorou a qualidade das gravações externas, por outro, permitiu também maior controle sobre o conteúdo das mensagens: passou a ser viável fragmentar as entrevistas, depoimentos, etc. e remontar os trechos selecionados, procedimento que se tornou rotineiro (ORTRIWANO, 2002-2003, p. 76).

Ressaltamos, porém, que de todas as inovações do período após o fim da chamada "Era de Ouro" e que muito contribuíram à sobrevivência do meio, o transistor foi o grande responsável, enquanto tecnologia, para a reinvenção do rádio e a evolução da produção da reportagem, principalmente da externa. Foi o transistor que proporcionou outras novidades eletrônicas da época. O próprio gravador, ao se transistorizar, impulsionou mais ainda a reportagem, em especial na exploração das características radiofônicas de mobilidade e imediatismo. E ao servir para disseminar as unidades móveis de transmissão, impulsionou e consolidou, no dia a dia do radiojornalismo, a prática das reportagens externas ao vivo.

O transistor permitiu, ainda, o desenvolvimento de aparelhos portáteis de recepção, culminando na famosa expressão de que "o rádio saiu da sala e foi para a cozinha". Mas essa novidade tecnológica, que susbstituiuas velhas e grandes válvulas, também influenciou a transmissão das mensagens radiofônicas, garantindo definitivamente a mobilidade tanto para o emissor quanto para o receptor. "A tecnologia do transistor surgiu no dia 23 de dezembro de 1947. A proposta, apresentada por cientistas da Bell Telephone Laboratories, tinha como objetivo ampliar sinais elétricos através do uso de gerânio como material semicondutor" (LOPEZ, 2009, p.4). Para Sônia Virgínia Moreira (1999, p.212), a invenção popularizou e massificou o aparelho receptor:

A invenção do transistor, em 1947, tornou o rádio acessível, de fácil manuseio e preço reduzido. Depois dos anos 60 , os aparelhos transistores miniaturizados, portáteis e baratos invadiram o mercado ocidental e assinalaram o início da massificação do rádio em países do Terceiro Mundo onde, na

João Pessoa-Brasil | ANO 7 VOL.7 N.1 | JAN./JUN. 2020 | p. 220-238 


\section{ANEORA}

Valci Regina Mousquer ZUCULOTO . Arnaldo ZIMMERMANN

falta de energia elétrica, funcionava a bateria. (MOREIRA, 1999, p.212)

A novidade aportou no Brasil na década de 1950 e se popularizando na década seguinte, transformou marcadamente a forma de cobertura jornalística, com a possibilidade de narrar o fato direto do local do acontecimento. "O jornalismo destacou-se no período, mostrando agilidade na cobertura de notícias, com entradas ao vivo, diretamente do local onde aconteciam os fatos, e com entrevistas realizadas fora do estúdio" (NEUBERGER, 2012, p.72).

A facilidade de deslocamento com os novos e menores equipamentos de apuração, produção e transmissão fez com que a reportagem radiofônica, em moldes como conhecemos até hoje, de vez estivesse presente na programação das emissoras e explorasse cada vez mais a mobilidade, o imediatismo, a ubiquidade e a instantaneidade. Intervenções e entrevistas ao vivo, diretamente dos locais e nos momentos exatos dos acontecimentos passaram a constituir o cotidiano dos repórteres.

Para Luiz Beltrão, novas fronteiras foram derrubadas por intermédio da tecnologia: "o transistor permitiu a sintonização do homem com seus irmãos distantes, sem quaisquer barreiras" (BELTRÃO, 1968, p.113 apud GOMES, 2014, p.54). O semiólogo Roland Barthes, em seu ensaio "A escrita do acontecimento", observou o protagonismo alçado ao rádio nos movimentos de maio de 1968, em Paris, devido à nova tecnologia aplicada ao meio: "o transistor tornou-se apêndice corporal, a prótese auditiva, o novo órgão de ficção científica de certos manifestantes; pela repercussão imediata do ato, ela inflectia, modificava o acontecimento" (BARTHES, 2008, p.214).

Se na fase do "Rádio Pioneiro" a leitura direta de jornais impressos no ar era a característica embrionária do radiojornalismo e a dependência das informações das agências de notícias dominaram o período da "Era de Ouro", a reportagem radiofônica passou a ser o fator diferencial do jornalismo 
DO TRANSISTOR AO CELULAR: anotações históricas sobre transformações da reportagem radiofônica a partir de tecnologias

radiofônico no período "Pós-televisão", com apuração e produção própria das informações.

De acordo com Mauro de Felice (1981, p.69), nesta fase, linhas de telefonia exclusivas e microfones eram instalados antecipadamente em locais de eventos pautados para cobertura das emissoras: "operadores e radiorrepórteres saíam juntos para as tarefas, e a primeira providência era a instalação de microfones nos locais onde se realizariam as solenidades". A evolução na disponibilização de linhas telefônicas, devido a melhorias nas telecomunicações brasileiras e à transmissão via micro-ondas em meados da década de 60, também garantiram um impulso do "ao vivo" nas reportagens.

Em 1955, no início da era do transistor, o número de aparelhos receptores de rádio no Brasil ainda era limitado. Segundo Klöckner (2008, p.25), nessa época eram "477 emissoras de rádio e o total de aparelhos receptores atingia quase um milhão". Na equação entre aparelhos transmissores móveis e menores - como gravadores portáteis e estações móveis nos automóveis - e a miniaturização dos aparelhos receptores, surge também a preocupação com o conteúdo e a linguagem adotada no jornalismo a partir de então: "as sonoras das reportagens tornaram-se menores para que a mensagem não provocasse dispersão da audiência. $O$ trabalho do repórter e a naturalidade das histórias se esvaíram, impostos pela "'nova ordem"' de modificação da linguagem" (FERRAZ, 2016, p.70). Sem a possibilidade de redação prévia de textos a partir da coleta de informações nas ruas, o tom coloquial de repórteres e apresentadores começa a desenhar o estilo de comunicação jornalística que reinaria nas décadas seguintes, com cada vez mais ênfase no "ao vivo"e no improviso.

Para Ferraz (2016), as novas possibilidades técnicas causaram uma profunda modificação no conteúdo radiojornalístico: "a informação no rádio, sendo feita ao vivo, passou a exigir dos jornalistas que iam ao ar o improviso no lugar de textos escritos, tanto dos que estavam no estúdio, quanto dos que

João Pessoa - Brasil | ANO 7 VOL.7 N.1 | JAN./JUN. 2020 | p. 220-238 


\section{ANEORA}

Valci Regina Mousquer ZUCULOTO . Arnaldo ZIMMERMANN

estavam na rua" (FERRAZ, 2016, p.72). Conforme Gomes (2014), as unidades móveis de transmissão instaladas nos carros das emissoras colocaram o jornalista no ambiente de pauta, podendo finalmente relatar ao vivo os acontecimentos em tempo real. Porém, com mensagens curtas, já que os equipamentos eram alimentados pela bateria do automóvel.

Marco importante na realização de reportagens externas radiofônicas foi o início dos "Comandos Continental", na Rádio Continental do Rio de Janeiro, no começo da década de 1950, priorizando o jornalismo direto nas ruas. "Era realmente uma maneira de priorizar a rua e a transmissão externa em detrimento da produção de notícias, que geralmente é feita de dentro da emissora" (BESPALHOK, 2006, p.69). O slogan da Continental era "A que está em todas", fazendo justamente referência à transmissão das notícias diretamente dos locais do acontecimento. A cobertura jornalística dos "Comandos Continental" nas ruas do Rio de Janeiro, também inaugurando o uso de carros como unidades móveis específicas para externas, igualmente fornecia informações para a redação dos noticiários que ainda mantinham a fórmula "Esso" de transmissão de notícias (ZUCULOTO, 2012, p. 109-110).

Segundo Bespalhok (2006), a emissora usava, na época, dois microfones sem fio chamados de BTP em suas externas e trabalhava diariamente com dois carros volantes. Um deles cobria pautas previamente agendadas e o outro percorria a cidade em busca do inusitado e do inesperado, especialmente assuntos como assaltos, incêndios, enchentes ou desabamentos (BESPALHOK, 2006, p.71-72). Os microfones BTP5, utilizados pela Continental nas décadas de 1950 e 1960, gradualmente foram

\footnotetext{
${ }^{5} \mathrm{O}$ BTP era um microfone portátil com aproximadamente 40 centímetros de altura, com duas alças de ferro, movido à bateria e operando como um pequeno transmissor. Necessitava que um operador de áudio à distância sintonizasse o som do microfone para fazer as transmissões externas (GOMES apud BESPALHOK, 2006, p.190).
} 
substituídos, nos anos de 1970 a 1990, por transmissores menores do tipo HT (Hand talk). Isto ocorreu na maioria das emissoras de rádio do país.

\section{A era do celular e o novo impulso à reportagem de rádio}

No período entre 1960 e 1990, as emissoras continuaram a utilizar diferentes modelos de microfones sem fio e linhas telefônicas fixas para transmistir reportagens externas. No caso das linhas telefônicas, as mesmas eram instaladas com antecedência nos locais programados, não se configurando, portanto, em coberturas jornalísticas de fatos imprevistos pelas equipes de jornalismo.

Já as Unidades Móveis instaladas nos carros das estações, garantiam uma cobertura mais factual, pela possibilidade de aproximação física com o local do acontecimento. Essas unidades eram "sistemas de rádiotransmissores de médio alcance que serviam como canal de comunicação direta entre a redação e o jornalista" (ZUCHI, 2004, apud LOPEZ, 2009, p.473).

0 telefone fixo também teve um papel essencial nas reportagens radiofônicas, mas com uma validade parcial, já que não acompanhava a movimentação do fato e "exigia que o jornalista, muitas vezes, se ausentasse do palco da ação para realizar a transmissão e, com isso, perdesse informações" (LOPEZ, 2009, p.473). Muitos repórteres chegavam a utilizar telefones privados e telefones públicos (orelhões) para a transmissão o mais próximo possível de um acontecimento.

Com a chegada dos telefones celulares no Brasil em 1990, a reportagem externa no rádio finalmente ficaria livre de fios, baterias de automóveis e de uma limitação mais rígida no tempo de transmissão imposto pelos aparelhos das gerações anteriores. A primeira ligação oficial de um protótipo de telefone celular no planeta foi realizada em 1973, em Nova York, pelo engenheiro Martin Cooper, da Motorola. Mas, no Brasil, a novidade só começou a ser utilizada a partir de dezembro de 1990, no Rio de Janeiro, com a chegada do 


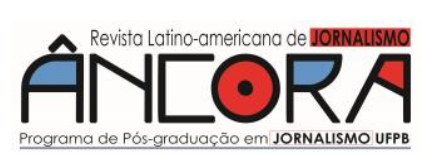

Valci Regina Mousquer ZUCULOTO . Arnaldo ZIMMERMANN

primeiro modelo de celular no país, o Motorola PT 550, com 22 centímetros e pesando 348 gramas (FOLHA DE SÃO PAULO, 2017).

Com o advento da telefonia móvel através do aparelho celular, "os repórteres poderiam ser localizados a qualquer momento, para que fossem mobilizados para uma cobertura factual, com fronteiras de transmissão mais tênues do que as anteriores, com as unidades móveis" (LOPEZ, 2009, p.7). Conforme Meditsch (2007), o radiojornalismo ao vivo, como fator dominante nas programações informativas, só foi possível com o avanço paralelo nas telecomunicações.

A telefonia móvel celular e a telefonia direta por satélite romperam os últimos obstáculos à mobilidade na produção, dispensaram a necessidade de instalação de sistemas próprios de radiocomunicação com os repórteres, nas emissoras, e aumentaram a autonomia dos jornalistas em relação aos controles governamentais, exercidos através das redes físicas (MEDITSCH, 2007, p.116).

Com a popularização dos celulares nos primeiros anos da década de 1990, não só repórteres ampliaram sua capacidade de transmitir informações em tempo real, direto do local dos acontecimentos, como também ouvintes passaram a gerar pauta e conteúdo para a reportagem e equipes de jornalismo. Marcelo Parada (2000) recorda que o telefone celular, em sua fase inicial, transformou a reportagem radiofônica e também a participação da audiência, no papel do chamado "ouvinte-repórter". A cobertura do trânsito e outras ocorrências externas tiveram grande modificação, sendo possível "informar tudo em tempo real, antes mesmo que a polícia" (PARADA, 2000, p.116). O advento do celular também produziu nova dinâmica de relação com fatos e fontes, na percepção de Gomes:

O relacionamento com as fontes também foi beneficiado com a novidade. Estas passaram a ser localizadas e ouvidas em qualquer lugar e mesmo em deslocamento. Para o repórter que sai para uma externa, a checagem da pauta pode ser realizada já durante 0 percurso para o local do acontecimento, ouvindo pessoas e recebendo dicas da produção por meio dos recursos da telefonia móvel. (GOMES, 2014, p.82) 
DO TRANSISTOR AO CELULAR: anotações históricas sobre transformaçães da reportagem radiofônica a partir de tecnologias

Ao longo da década de 1990, o uso dos telefones celulares pelas emissoras de rádio foi de aplicação predominantemente sonora, já que a tecnologia ainda dava os passos iniciais para a transmissão de textos, via SMS ${ }^{6}$ e internet. Naquela fase, outros equipamentos com tecnologia digital já alteravam determinantemente a rotina de produção e edição de reportagens e conteúdos radiofônicos:

Em termos de equipamentos digitais para produção, gravação e arquivamento, os programas radiofônicos, em poucos anos, passaram rapidamente por diferentes tecnologias digitais de registro: Mini disc (MD), Digital Audio Tape (DAT), Digital Compact Cassete (DCC). O uso desses equipamentos digitais permitiu, principalmente, reprodução infinita sem perda de qualidade, sem degeneração de cópia; fácil manejo; grande capacidade e facilidade de armazenamento; busca rápida e facilitada do segmento desejado; e edição não linear (ZUCULOTO, 2012, p.154).

A partir do novo milênio, porém, o avanço da tecnologia das telecomunicações, através do telefone celular, alça o rádio do mundo sonoro para o mundo audiovisual e multimídia. Isto ocorreu quando celulares, convertidos contemporaneamente em smartphones, passam a fotografar, filmar, gravar áudio e, principalmente, navegar livremente pela internet com as tecnologias 3G, 4G e "Wi-fi".

O primeiro aparelho com características de smartphone foi lançado mundialmente em 19947 (BBC NEWS BRASIL, 2014), mas o marco tecnológico acabou sendo o ano de 2007, com o primeiro Iphone pela Apple (GAMBARO, 2019), consolidando acesso à internet (em 2G), mídias sociais e aplicativos diversos. A conectividade $3 \mathrm{G}$ e a loja de aplicativos vieram a partir do segundo modelo do Iphone, em 2008. O mesmo ano em que a Google lançou seu

\footnotetext{
${ }^{6}$ As primeiras mensagens de SMS (Short Messaging Service) por celular no mundo foram enviadas em 3 de dezembro de 1992, pelo engenheiro Neil Papworth no Reino Unido. Fonte: https://olhardigital.com.br/noticia/primeira-mensagem-sms-completa-25-anos/72733

${ }^{7} \mathrm{Em} 16$ de agosto de 1994 a IBM iniciou as vendas do Simon, uma combinação inédita até então de telefone celular com tecnologias de computação. Fonte: https://www.bbc.com/portuguese/noticias/2014/08/140815_smartphone_vinte_anos_rb. Acesso em 02 de fev. 2020.
}

João Pessoa-Brasil | ANO 7 VOL.7 N.1 | JAN./JUN. 2020 | p. 220-238 


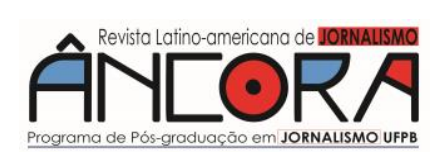

Valci Regina Mousquer ZUCULOTO . Arnaldo ZIMMERMANN

sistema operacional Android e sua loja de aplicativos (UOL, 2017), que chegam no Brasil somente em 2009 (ÉPOCA NEGÓCIOS, 2009).

A independência na transmissão sonora conquistada pelo repórter com o transistor nos anos de 1950 e potencializada com os primeiros celulares na década de 1990, passa a agregar a possibilidade de captação, produção, edição e circulação diretamente das ruas, como reforça Gomes:

O incremento crescente dos aparelhos celulares possibilita a gravação e o envio de sonoras, com o uso de internet sem fio, potencializando a agilidade característica do meio. Com um notebook, gravador digital e acesso à web, a produção de rádio pode ser feita integralmente fora da emissora; é o radiojornalismo produzido em ambiente móvel. (GOMES, 2014, p.90-94)

Para Gambaro (2019, p.258), as funções do repórter foram mais uma vez alteradas com a chegada do smartphone. Além de ser o primeiro a dar a notícia ao vivo na programação, também passa a cumprir tarefas durante as externas com fotos, vídeos e texto a partir do aparelho.

No aspecto da emissão da reportagem em áudio, os smartphones trouxeram ainda mais algumas ferramentas úteis à produção e à circulação do conteúdo. Uma delas foi o gravador digital acoplado aos aparelhos, diminuindo a quantidade de equipamentos nas saídas do repórter à rua. A outra modificação foi o uso de aplicativos de mensagens instantâneas como o WhatsApp, ferramenta incorporada pelas emissoras de rádio no Brasil desde 2013 (KISCHINHEVSKY, 2016) e hoje utilizada tanto para envio de áudio das ruas para a emissora, como para recebimento de mensagens sonoras da audiência, oferecendo uma nova configuração do papel de "ouvinte-repórter" incorporado às programações nos anos 1990.

Ocorre, neste novo cenário tecnológico, mais uma vez a reconfiguração de linguagens e de organização de pauta e produção na reportagem radiofônica. Consolida-se o improviso, sem uma completa elaboração/redação prévia, por parte dos repórteres, antes das entradas ao vivo na programação. Assim, mais e mais se aproximam da linguagem coloquial, da conversa com a audiência, defendida como a mais adequada à mensagem radiofônica. Esta 
DO TRANSISTOR AO CELULAR: anotações históricas sobre transformações da reportagem radiofônica a partir de tecnologias

(re)aproximação com o público vem a estabelecer um novo padrão de conversa e interação, tanto com o ouvinte passivo quanto com o partícipe.

\section{Considerações Finais}

Ao se (re)visitar principais percursos e balizas técnicas e tecnológicas que vêm permitindo ao radiojornalismo desenvolver um de seus fazeres basilares, a reportagem, mais uma vez é possível confirmar o quanto estas inovações estão histórica, indissociável e determinantemente imbricadas com a trajetória do jornalismo de rádio. Também dos usos que este faz das potenciais características do meio, sobretudo da mobilidade, imediatismo, instantaneidade e ubiquidade. Características que se transformam, mas permanecem, algumas inclusive mais radicalizadas, mesmo na contemporaneidade, quando o rádio da era virtual se expande para além das antenas. Transbordando para internet, onde se executa não apenas nos sites das emissoras hertzianas e nas exclusivas webrádios, também transmitindo via redes sociais, novos suportes e plataformas.

Para se compreender este contexto contemporâneo, em que o rádio se reinventa, ocupando e resistindo, agora também no ambiente de convergência multimídia e de multiplataformas de produção, veiculação e transmissão, é importante revisar o passado, tanto o mais distante quanto o mais recente. Pode-se encontrar novas pistas e vestígios, fazer novas leituras para observação da atualidade.

Optamos, aqui, por (re)visitar a trajetória do rádio e de suas tecnologias com recorte naquelas que se evidenciaram mais determinantes, não somente para o meio, mas, em especial, para a reportagem radiofônica externa. Isto para constituir bases à pesquisa maior sobre a sua reconfiguração contemporânea. Embora nosso recorte temporal tenha se concentrado entre a década de 1950 e os dias atuais (do transistor ao celular e ao smartphone), a recuperação de aspectos históricos da fase pré-transistor, com a introdução 


\section{ÂNCORA}

Valci Regina Mousquer ZUCULOTO . Arnaldo ZIMMERMANN

do radiojornalismo no Brasil, e o período de desdobramentos do uso do celular, chegando até a contemporaneidade, tornaram-se essenciais para a compreensão dessa linha histórica.

Na presente (re)constituição, justamente quando o rádio no Brasil passa por seu centenário, considerando-se a entrada no ar da Rádio Clube de Pernambuco, em 1919, corroboramos entendimentos, acentuados em nossas pesquisas sobre suas transformações históricas, de que o meio é um dos mais adequados à transmissão do jornalismo. Assim, em especial, por suas características de mobilidade, imediatismo, instantaneidade e ubiquidade, potencializadas pelas tecnologias ao longo de seu percurso.

E como foi possível observar ao se proceder esta revisão histórica, ao aumentar suas capacidades para ser um dos meios mais ágeis tanto na captação, produção como na transmissão das informações, impacta sobretudo a prática da reportagem. Potencial que vem aumentando, principalmente em decorrência da evolução das suas tecnologias, e que no decorrer de sua história não tem sido totalmente explorado e utilizado. Nas reportagens é onde mais praticamos - ou podemos praticar - o uso de características e recursos do rádio e sua linguagem específica.

Como diz Marialva Barbosa em entrevista à Revista Uninter de Comunicação (HECK et al, 2019), "[...] tem um passado que deve ser compreendido [...] Não há presente absoluto, esse está inserido em uma linha temporal que vem do passado até agora, e esses processos se complexificam ao longo desse tempo. " Conhecer e compreender a trajetória de constituição do radiojornalismo, com ênfase na sua fundamental prática que é a reportagem, torna-se, portanto, essencial para o entendimento do seu cenário contemporâneo e do atual fazer radiojornalístico.

\section{Referências}

BARBOSA, Marialva. (org.). Os manuscritos do Brasil - Uma rede de textos no longo século XIX. Niterói-RJ: Editora da Universidade Federal 
Fluminense - EDUFF, 2017.

BARTHES, Roland. A Escrita do acontecimento. In: MEDITSCH, Eduardo; ZUCULOTO, Valci. (org.). Teorias do rádio: textos e contextos.

Florianópolis: Insular, vol. II, 2008, p. 213-218.

BELTRÃO, Luiz. Jornalismo interpretativo: filosofia e técnica. Porto Alegre: Sulina, 1976.

BESPALHOK, Flávia Lucia Bazan. Reportagem Externa Radiofônica: A Experiência da Emissora Continental na Construção da História do Radiojornalismo Brasileiro. In.: Congresso Brasileiro da Comunicação, 28, 2005, Rio de Janeiro. Anais[...] São Paulo: INTERCOM, 2005. Disponível em: < http://www. intercom.org.br/papers/nacionais/2005/resumos/R13371.pdf> Acesso em: mai., 2019.

BESPALHOK, Flávia Lucia Bazan. A prática da reportagem radiofônica na Emissora Continental do Rio de Janeiro. Dissertação (mestrado) Universidade Estadual Paulista, Faculdade de Arquitetura, Artes e Comunicação. Bauru, SP. 2006. p. 340. Disponível em: <http://hdl.handle.net/11449/89453>. Acesso em jun., 2019.

FELICE, Mauro de. Jornalismo de Rádio. Brasília: Thesaurus Editora, 1981. FERRAZ, Nivaldo. Reportagem no rádio: realidade brasileira, fundamentação, possibilidades sonoras e jornalísticas a partir da peça radiofônica reportagem Tese (Doutorado) Escola de Comunicação e Artes, Universidade de São Paulo. São Paulo, SP. 2016. p. 396. Disponível em: $<$ http://www.teses.usp.br/teses/disponiveis/27/27161/tde-25072017150144/pt-br.php>. Acesso em: jun., 2019.

Do 'isto fala' ao 'zap zap'. Folha de São Paulo. São Paulo, ano 97, n. 32.404, p. 8, 21 dezembro 2017. Disponível em:

$<$ https://acervo.folha.com.br/leitor.do?numero $=48108 \&$ anchor $=6074416 \&$ ori gem=busca\&pd=41aaea39871317aefb3c5f19b572604c >. Acesso em: jun., 2019.

GAMBARO, Daniel. A instituição social do rádio: (re)agregando as práticas discursivas da indústria no ecossistema midiático. 2019. Tese. (Doutorado) - Programa em Pós-graduação em Meios e Processos Audiovisuais, Escola de Comunicação e Artes, Universidade de São Paulo, São Paulo, 2019.

GOMES, Juliana. Impactos da mobilidade do rádio na produção do radiojornalismo: um estudo dos programas Gaúcha Repórter e Notícia na Tarde. Dissertação (Mestrado) - Universidade Federal de Santa Catarina, 


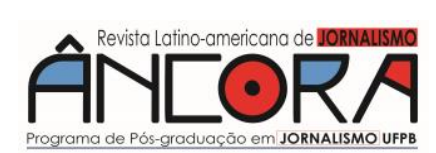

Valci Regina Mousquer ZUCULOTO . Arnaldo ZIMMERMANN

Centro de Comunicação e Expressão, Programa de Pós-Graduação em Jornalismo, Florianópolis, 2014. p. 185 Disponível em:

http://www.bu.ufsc.br/teses/PJOR0065-D.pdf. Acesso em: jun., 2019. Há 10 anos, lançamento do primeiro iPhone iniciava revolução no mundo. UOL. São Paulo, 09 jan. 2017. Disponível em:

<https://www.uol.com.br/tit/noticias/redacao/2017/01/09/ha-10-anoslancamento-do-primeiro-iphone-iniciava-revolucao-no-mundo.htm>. Acesso em: 01 fev. 2020.

HECK, Ana Paula et al. Mirar o presente olhando o passado: o risco do foco presentista nos estudos de comunicação permeados pela mídia.

Entrevista com Marialva Barbosa. Revista Uninter de Comunicação. Curitiba, v. 7, n.12, p. 129-131, jun. 2019.

KISCHINHEVSKY, Marcelo. Rádio e mídias sociais: mediações e interações radiofônicas em plataformas digitais de comunicação. 1. ed. Rio de Janeiro: Mauad X, 2016.

KLÖCKNER, Luciano. O Repórter Esso: a síntese radiofônica mundial que fez história. Porto Alegre: EDIPUCRS, 2008.

LOPEZ, Débora Cristina. Marcos tecnológicos do radiojornalismo no Brasil: uma revisão histórica. In: KLÖCKNER, Luciano; PRATA, Nair (org.). A história da mídia sonora: experiências, memórias e afetos de nortea sul do Brasil. Porto Alegre: Edipucrs, 2009.

MAUAD, Ana Maria; ALMEIDA, Juliane Rabelo de; SANTHIAGO, Ricardo (org.). História Pública no Brasil - sentidos e itinerários. São Paulo: Letra e Voz, 2016.

MAUAD, Ana Maria; SANTHIAGO, Ricardo; BORGES, Viviane Trindade (org.). Que história pública queremos? São Paulo: Letra e Voz, 2018. MEDITSCH, Eduardo. O rádio na era da informação: teoria e técnica do novo radiojornalismo. $2^{a}$ ed. rev. Florianópolis: Insular; Ed. UFSC, 2007. MOREIRA, Sônia Virgínia. Rádio@Internet. In: BIANCO, Nélia R. Del Bianco; MOREIRA, Sônia Virgínia (org.). Rádio no Brasil: Tendências e Perspectivas. Rio de Janeiro: EdUERJ; Brasília, DF: UnB, 1999. MOSER, Magali. Apontamentos sobre a invenção da reportagem. In.: Congresso Brasileiro da Comunicação, 41, 2018. Joinville, SC. Anais[...] São Paulo: INTERCOM, 2018. Disponível em: http://portalintercom.org.br/anais/nacional2018/resumos/R13-0449-1.pdf Acesso em: jun., 2019.

NEUBERGER, Rachel Severo Alves. O Rádio na Era da Convergência das Mídias. Cruz das Almas/BA: UFRB, 2012. Disponível em: 
< https://blog.ufba.br/portaldoradio/files/2012/10/O-r\%C3\%A1dio-na-era-daconverg\%C3\%AAncia1.pdf>. Acesso em: jun., 2019.

\section{ORTRIWANO, Gisela Swetlana. Os (des) caminhos do}

radiojornalismo. Tese (Doutorado em Ciências da Comunicação) -

Universidade de São Paulo, Escola de Comunicação e Artes, São Paulo. São

Paulo, SP. 1990.

ORTRIWANO, Gisela Swetlana. Radiojornalismo no Brasil: fragmentos de uma história. In.: REVISTA USP, São Paulo, n.56, p. 66-85, dez/fev 20022003. Disponível em:

http://www.revistas.usp.br/revusp/article/download/33808/36546/. Acesso em: jun., 2019.

PARADA, Marcelo. Rádio: 24 horas de jornalismo. São Paulo: Editora Panda, 2000.

Primeiro smartphone completa 20 anos. BBC News Brasil. São Paulo, 16 ago. 2014. Disponível em:

<https://www.bbc.com/portuguese/noticias/2014/08/140815_smartphone_vi nte_anos_rb>. Acesso em: $01 \mathrm{fev} .2020$.

Primeiros celulares com Android chegam ao Brasil. Época Negócios. São Paulo, 17 set. 2009. Disponível em:

<http://colunas.revistaepocanegocios.globo.com/tecneira/2009/09/17/primei ros-celulares-com-android-chega-ao-brasil-em-outubro/> . Acesso em: 01 fev. 2020.

ZUCULOTO, Valci Regina Mousquer. No ar: a história da notícia de rádio no Brasil. Florianópolis: Insular, 2012. 